\title{
The influence of hepatitis B virus on antiviral treatment with interferon and ribavirin in Asian patients with hepatitis $C$ virus/hepatitis B virus coinfection: a meta-analysis
}

Jun-Ying Liu, Yun-Jian Sheng, Huai-Dong Hu, Qing Zhong, Jing Wang, Shi-Wen Tong, Zhi Zhou, Da-Zhi Zhang, Peng $\mathrm{Hu}^{*}$ and Hong Ren ${ }^{*}$

\begin{abstract}
Background: Clinical and laboratory studies have indicated that coinfection with hepatitis B virus (HBV) and hepatitis $\mathrm{C}$ virus (HCV) can suppress one another, eliciting a dominant disease phenotype. To assess whether HBV can influence the antiviral effect of treatment on $\mathrm{HCV}$, we performed a meta-analysis to comparatively analyze the response to interferon plus ribavirin treatment in patients with HBV/HCV coinfection and HCV mono-infection.

Methods: Published studies in the English-language medical literature that involved cohorts of HBV/HCV coinfection and HCV mono-infection were obtained by searching Medline, Cochrane and Embase databases. Studies that compared the efficacy of treatment with interferon plus ribavirin in HBV/HCV coinfection and HCV mono-infection were assessed. End-of-treatment virological response (ETVR), sustained virological response (SVR), HCV relapse rate, and alanine aminotransferase (ALT) normalization rate were compared between HBV/HCV coinfection and HCV mono-infection patients.
\end{abstract}

Results: Five trials involving 705 patients were analyzed. At the end of follow-up serum ALT normalization rates in patients with HCV mono-infection were significantly higher than in patients with HBV/HCV coinfection (odds ratio $(\mathrm{OR})=0.56,95 \%$ confidence interval $(\mathrm{Cl}): 0.40-0.80, P=0.001)$. The ETVR and SVR achieved in HBV/HCV coinfection patients were comparable to those in HCV mono-infection patients $(\mathrm{OR}=1.03,95 \% \mathrm{Cl}: 0.37-2.82, P=0.96$ and $\mathrm{OR}=0.87,95 \% \mathrm{Cl}: 0.62-1.21, P=0.38$, respectively). The rate of relapse for HCV or HCV genotype 1 was not significantly different between HBV/HCV coinfection patients and HCV mono-infection patients $(\mathrm{OR}=1.55,95 \%$ $\mathrm{Cl}: 0.98-2.47, P=0.06$; HCV genotype 1: $\mathrm{OR}=2.4,95 \% \mathrm{Cl}: 1.17-4.91, P=0.19$ ).

Conclusions: Treatment with interferon and ribavirin achieves similar ETVR and SVR in HBV/HCV coinfection and HCV mono-infection. HBV/HCV coinfection patients had distinctively lower end of follow-up serum ALT normalization.

Keywords: Coinfection, Hepatitis B, Hepatitis C, Interferon, Ribavirin

\footnotetext{
* Correspondence: hp_cq@yahoo.com.cn; renhong0531@vip.sina.com

Department of Infectious Diseases, Institute for Viral Hepatitis, Key Laboratory of Molecular Biology for Infectious Diseases, Ministry of Education, Second Affiliated Hospital of Chongqing Medical University, Chongqing 400010, China
} 


\section{Background}

Hepatitis B virus (HBV) and hepatitis $\mathrm{C}$ virus (HCV) are significant human pathogens of global concern. Infection with either hepatitis virus can lead to chronic liver disease, severely degrading quality of life and eventually causing death. The infection elicits a persistent host inflammatory response, which is accompanied by activation of biomolecule signaling cascades that can promote chronic hepatitis, liver cirrhosis, and/or hepatocellular carcinoma (HCC) [1-3].

These two hepatotropic viruses share the same modes of transmission and often appear as a coinfection in geographic locales where HBV or HCV is considered endemic [4-6]. In Taiwan, 11\% of patients with HBV-related chronic liver disease also presented with positive immunoreactivity for anti-HCV antibody [5,7]; likewise, $12 \%$ of the Taiwanese anti-HCV positive patients had detectable levels of hepatitis B surface antigen (HBsAg) in their serum [4]. In Italy, up to $40 \%$ of patients with chronic hepatitis B (CHB) have been reported as anti-HCV positive [8]. Moreover, occult HBV infection has been described in patients with chronic hepatitis $\mathrm{C}(\mathrm{CHC})[9,10]$.

Several clinical and laboratory studies have investigated the potential interactions of $\mathrm{HBV}$ and $\mathrm{HCV}$ and their concomitant affects on the immune response; these studies have revealed that HBV and HCV are capable of suppressing replication of one other in coinfection conditions [11-14]. Clinically, patients with $\mathrm{HBV} / \mathrm{HCV}$ coinfection have a much higher risk of developing cirrhosis, hepatic failure, and HCC than patients with HBV or HCV mono-infection [14-19].

The current gold standard treatment of $\mathrm{CHC}$ is a combination pharmacotherapy using pegylated (PEG) interferon (IFN) and ribavirin [20-22]. Interferon has also been shown as an effective treatment for CHB [23,24]; however, interferon alone is not effective in clearing $\mathrm{HCV}$ from patients with HBV/HCV coinfection [25-29]. The combination treatment strategy of interferon plus ribavirin is more effective for $\mathrm{HCV}$ clearance in patients with $\mathrm{HBV} / \mathrm{HCV}$ coinfection, and current treatment guidelines recommend this approach. However, the efficacy of combination treatment in HBV/HCV coinfection has yet to be definitively evidenced as equal to that in HCV mono-infection [30-32]. To this end, we performed a comparative analysis of the therapeutic efficacy of interferon plus ribavirin reported from cohort studies of patients with $\mathrm{HBV} / \mathrm{HCV}$ coinfection and $\mathrm{HCV}$ monoinfection by undertaking a meta-analysis according to PRISMA (Transparent Reporting of Systematic Review and Meta-analyses) criteria [33] (Additional file 1).

\section{Methods}

Literature search

Relevant studies were identified by searching the Medline, Embase, and Cochrane databases, using the following medical subject headings: "hepatitis B virus and hepatitis $C$ virus coinfection", "hepatitis B virus and hepatitis $\mathrm{C}$ virus dual infection", "interferon and ribavirin", and "antiviral therapy". The scope of the search was restricted to "human" and "English". We included all cohort studies. The search was carried out in March 2011, without a lower date limit for the search results. The reference lists of all retrieved review articles were manually searched to identify potentially relevant articles missed by the computer search. We used only previously published data, so approval from the ethics committee was not required.

\section{Inclusion and exclusion criteria}

Inclusion criteria for the meta-analysis were as the follows: (1) cohort study design (each group sample size >10); (2) study including an $\mathrm{HBV} / \mathrm{HCV}$ coinfection group and an HCV mono-infection group; and (3) patients of two groups treated with interferon plus ribavirin. Patient populations were excluded if they featured: (1) coinfection with hepatitis A, D, or E virus, or human immunodeficiency virus (HIV); (2) diagnosis of autoimmune hepatitis, primary biliary cirrhosis, Wilson's disease, decompensated cirrhosis, or overt hepatic failure; (3) clinical evidence of HCC; (4) current or past history of alcohol abuse (alcohol intake $\geq 20 \mathrm{~g}$ daily); or (5) use of antiviral drugs or immunomodulatory drugs at any time within the preceding six months. Any dataset for which sufficient analytic information was not available was also excluded from the meta-analysis.

\section{Efficacy measures}

The primary efficacy end-point was sustained virological response (SVR), which was defined as the proportion of patients with undetectable serum HCV-RNA for at least 24 weeks after treatment. Secondary end points were: end-of-treatment virological response (ETVR), defined as the proportion of patients with undetectable serum HCV-RNA at the end of treatment; biochemical response, defined as normalization of serum alanine aminotransferase (ALT); viral relapse, defined as the proportion of patients with undetectable serum $\mathrm{HCV}$ RNA at the end of treatment but with detectable serum HCV-RNA at follow-up; and viral interaction of HBV and $\mathrm{HCV}$ in $\mathrm{HCV} / \mathrm{HBV}$ coinfection patients.

\section{Data extraction}

Two authors (Liu and Sheng) independently evaluated the retrieved studies according to the inclusion criteria and performed data extraction. The following data were extracted from each paper: (1) number of patients in the study; (2) details of the study design; (3) patient characteristics; (4) treatment doses and duration; and (5) 
outcome measures, as defined above. Disagreements were resolved by consensus.

\section{Study quality}

Quality of each study was independently assessed by the same two authors (Liu and Sheng) according to the following high-quality features: (1) cohort studies designed with case characteristics (clinical and/or demographic) matched to controls; and (2) presence of a definitive listing of inclusion and exclusion criteria for patients, along with clear definitions of treatment response. When discrepancies arose, a third party (Peng $\mathrm{Hu}$ ) was consulted.

\section{Statistical analysis}

Meta-analysis was performed using Review Manager Software 5.0 (Cochrane Collaboration, Oxford, United Kingdom), according to recommendations of the manufacturer and the Quality of Reporting of Meta-analyses (QUORUM) guidelines (DerSimonian R, Laird N, et al. 1986; Moher D, Cook DJ, et al. 2000). Statistical analysis for dichotomous variables was carried out. Outcomes were expressed as relative risks (RR) with 95\% confidence intervals $(\mathrm{CI})$. If the value 1 was included in the 95\% CI, the point estimate of the RR was considered to have reached statistical significance $(\mathrm{p}<0.05)$. The Isquared $\left(\mathrm{I}^{2}\right)$ statistic was used to measure the extent of inconsistency among the results. Heterogeneity was detected using the chi-square $\left(X^{2}\right)$ test. Since the $X^{2}$ test lacks power with few studies, we considered significant heterogeneity having been met when both the $X^{2}$ value was within the $10 \%$ level of significance $(P<0.10)$ and the $\mathrm{I}^{2}$ value exceeded $56 \%$. In cases where significant heterogeneity existed, the random effect model was used for analysis, otherwise the fixed effect model was used.

\section{Results}

\section{Search results and study characteristics}

A total of 111 studies were identified and screened for retrieval by using the strategy described above. After screening the title or abstract, 91 studies were excluded and 20 were retrieved and subjected to detailed evaluation. By adhering to the inclusion criteria, 15 of those studies were excluded. Finally, five cohort studies [30,32,34-36] were chosen for inclusion in the meta-analysis, which comprised a total of 705 patients (Figure 1).

The basic characteristics of each of the five studies are listed in Table 1 . The overall population ethnicity was Asian for all five studies, with one study [34] composed of Chinese and four $[30,32,34,36]$ composed of Taiwanese. Patients entered the cohorts from August 2000 to April 2007. The population size for each of the studies ranged from 54 to 321 . The mean age ranged from 44.9 [35] to 51.1 [32] years old. The percentage of males ranged from $61.5 \%$ [32] to $75.0 \%$ [34]. The mean HCV-

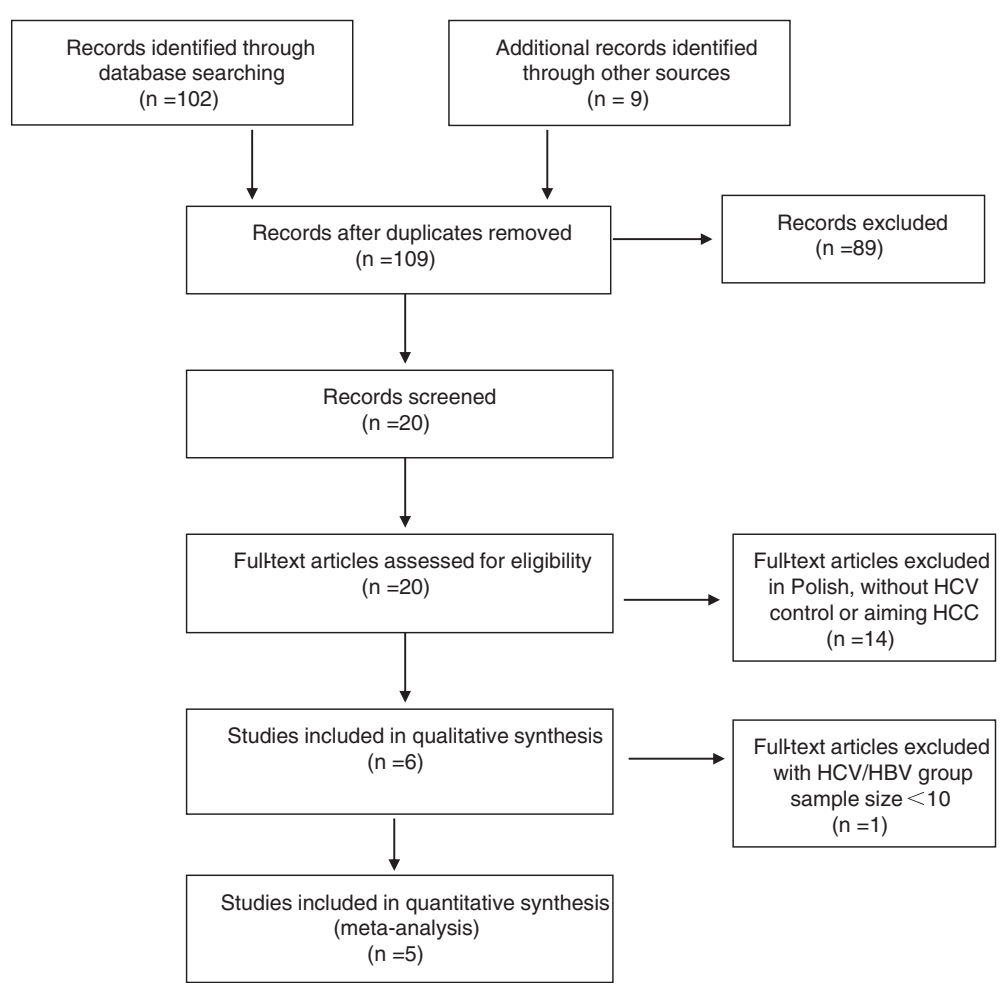

Figure 1 Flow diagram of the meta-analysis study selection process. 
Table 1 Characteristics of the clinical trials included in the meta-analysis

\begin{tabular}{|c|c|c|c|c|c|c|c|c|c|c|c|}
\hline \multirow[t]{2}{*}{ Study } & \multirow{2}{*}{$\begin{array}{l}\text { Geographic } \\
\text { locale }\end{array}$} & \multirow{2}{*}{$\begin{array}{l}\text { Study } \\
\text { design }\end{array}$} & \multirow{2}{*}{$\begin{array}{l}\text { Sample } \\
\text { size } \\
\text { (female/ } \\
\text { male) }\end{array}$} & \multirow{2}{*}{$\begin{array}{l}\text { Age in } \\
\text { years } \\
(\text { mean } \pm \text { SD) }\end{array}$} & \multirow{2}{*}{$\begin{array}{l}\text { HCV-RNA, } \\
\text { copies/mL } \\
(\text { mean } \pm \text { SD) }\end{array}$} & \multirow{2}{*}{$\begin{array}{c}\text { HCV } \\
\text { genotype 1/ } \\
\text { non-genotype } 1\end{array}$} & \multirow{2}{*}{$\begin{array}{l}\text { HBV-DNA, } \\
\text { copies/mL } \\
\text { (mea } \pm \text { SD) }\end{array}$} & \multirow{2}{*}{$\begin{array}{l}\mathrm{ALT}, \mathrm{U} / \mathrm{L} \\
(\mathrm{mean} \pm \mathrm{SD})\end{array}$} & \multicolumn{3}{|c|}{ IFN plus ribavirin regimen } \\
\hline & & & & & & & & & Drugs & Course, weeks & $\begin{array}{l}\text { Follow-up, } \\
\text { weeks }\end{array}$ \\
\hline \multirow[t]{2}{*}{ Yu et al. [35] } & \multirow[t]{2}{*}{ China } & \multirow[t]{2}{*}{ Cohort } & $C: 10 / 40$ & $44.9 \pm 9.6$ & $5.9 \pm 1.4 \log 10$ & C: $30 / 20$ & \multirow[t]{2}{*}{$4.6 \pm 0.9 \log 10$} & $97 \pm 19$ & \multirow{2}{*}{$\begin{array}{l}\text { PegIFN-a2a, } \\
\text { ribavirin }\end{array}$} & \multirow{2}{*}{$\begin{array}{l}\text { genotype 1: } 48 \\
\text { non-genotype } \\
\text { 1: } 24\end{array}$} & \multirow[t]{2}{*}{24} \\
\hline & & & M: 9/37 & $46.4 \pm 11.3$ & $6.3 \pm 1.3 \log 10$ & M: 25/21 & & $93 \pm 18$ & & & \\
\hline \multirow[t]{2}{*}{ Liu et al. [32] } & \multirow[t]{2}{*}{ Taiwan } & \multirow[t]{2}{*}{ Cohort } & C: $56 / 105$ & $51.1 \pm 10.3$ & $2.16 \pm 3.4 \times 10^{6}$ & C: $97 / 64$ & \multirow[t]{2}{*}{ UD- $4.22 \times 10^{5}$} & $121.0 \pm 85.0$ & \multirow{2}{*}{$\begin{array}{l}\text { PegIFN-a2a, } \\
\text { ribavirin }\end{array}$} & \multirow{2}{*}{$\begin{array}{l}\text { genotype } 1: 48 \\
\text { non-genotype } \\
1: 24\end{array}$} & \multirow[t]{2}{*}{24} \\
\hline & & & M: 71/89 & $48.9 \pm 10.5$ & $2.29 \pm 4.1 \times 10^{5}$ & M: 110/50 & & $126.1 \pm 81.8$ & & & \\
\hline \multirow[t]{2}{*}{ Chuang et al. [34] } & \multirow[t]{2}{*}{ Taiwan } & \multirow[t]{2}{*}{ Cohort } & C: $11 / 31$ & $45.04 \pm 10.7$ & $5.38 \pm 0.96 \log 10$ & $C: 21 / 21$ & \multirow[t]{2}{*}{$2.64 \pm 2.26 \log 10$} & $92.1 \pm 73.0$ & \multirow[t]{2}{*}{ IFN-a2b } & \multirow[t]{2}{*}{24} & \multirow[t]{2}{*}{24} \\
\hline & & & M: 22/62 & $44.9 \pm 11.2$ & $5.60 \pm 0.94 \log 10$ & M: 48/36 & & $141.1 \pm 105.5$ & & & \\
\hline \multirow[t]{2}{*}{ Hung et al. [30] } & \multirow[t]{2}{*}{ Taiwan } & \multirow[t]{2}{*}{ Cohort } & C: $14 / 22$ & $48.8 \pm 12.6$ & $5.80 \pm 1.10 \circ \mathrm{og} 10$ & C: $17 / 19$ & \multirow[t]{2}{*}{$N R$} & $125.8 \pm 89.3$ & \multirow[t]{2}{*}{ IFN-a2b } & \multirow[t]{2}{*}{24} & 24 \\
\hline & & & M: 28/44 & $48.3 \pm 12.0$ & $5.80 \pm 1.10 \operatorname{og} 10$ & M: $34 / 38$ & & $164.2 \pm 139.9$ & & & \\
\hline Liu et al. [36] & Taiwan & Cohort & C: $5 / 19$ & $46.5 \pm 13.2$ & $2.4 \pm 3.1 \times 10^{6}$ & C: $14 / 7$ & $1.3 \pm 2.5 \times 10^{3}$ & $137.0 \pm 81.0$ & IFN-a2a & 24 & 24 \\
\hline & & & M: 12/18 & $48.5 \pm 9.4$ & $1.9 \pm 2.2 \times 10^{6}$ & M: 17/13 & & $177.0 \pm 192.0$ & & & \\
\hline
\end{tabular}

$C \mathrm{HBV}$ and $\mathrm{HCV}$ coinfection, $M \mathrm{HCV}$ mono-infection, $N R$ not reported, $U D$ not detectable by the real-time $\mathrm{PCR}$ assay.

Table 2 Outcomes of the clinical trials included in the meta-analysis

\begin{tabular}{|c|c|c|c|c|c|c|c|c|c|c|c|c|c|c|}
\hline \multirow[t]{3}{*}{ Study } & \multirow{3}{*}{$\begin{array}{l}\text { Sample } \\
\text { size }(n)\end{array}$} & \multirow{2}{*}{\multicolumn{2}{|c|}{ HCV genotype $(n)$}} & \multicolumn{4}{|c|}{ End of treatment } & \multicolumn{7}{|c|}{ End of follow-up } \\
\hline & & & & \multicolumn{3}{|c|}{ HCV ETVR $(n)$} & \multirow{2}{*}{$\begin{array}{c}\text { ALT } \\
\text { normalization } \\
(n)\end{array}$} & \multicolumn{3}{|c|}{ HCV SVR $(n)$} & \multicolumn{3}{|c|}{ HCV relapse $(n)$} & \multirow{2}{*}{$\begin{array}{c}\text { ALT } \\
\text { normalization } \\
(n)\end{array}$} \\
\hline & & $\begin{array}{c}\text { Genotype } \\
1\end{array}$ & $\begin{array}{c}\text { Non- } \\
\text { genotype } 1\end{array}$ & Overall & $\begin{array}{c}\text { Genotype } \\
1\end{array}$ & $\begin{array}{c}\text { Non- } \\
\text { genotype } 1\end{array}$ & & Overall & $\begin{array}{c}\text { Genotype } \\
1\end{array}$ & $\begin{array}{c}\text { Non- } \\
\text { genotype } 1\end{array}$ & Overall & $\begin{array}{c}\text { Genotype } \\
1\end{array}$ & $\begin{array}{c}\text { Non- } \\
\text { genotype } 1\end{array}$ & \\
\hline \multirow{2}{*}{$\begin{array}{l}\text { Yu et al. } \\
\text { [35] }\end{array}$} & C: 50 & 30 & 20 & 46 & 27 & 19 & NR & 27 & 12 & 15 & 19 & 15 & 4 & $N R$ \\
\hline & M: 46 & 25 & 21 & 32 & 14 & 18 & NR & 26 & 11 & 15 & 6 & 3 & 3 & NR \\
\hline \multirow{2}{*}{$\begin{array}{l}\text { Liu et al. } \\
\text { [32] }\end{array}$} & C: 161 & 97 & 64 & 138 & 82 & 56 & NR & 123 & 70 & 53 & 15 & 12 & 3 & 103 \\
\hline & M: 160 & 110 & 50 & 141 & 95 & 46 & NR & 127 & 85 & 42 & 14 & 10 & 4 & 122 \\
\hline \multirow{2}{*}{$\begin{array}{l}\text { Chuang } \\
\text { et al. [34] }\end{array}$} & $C: 42$ & 21 & 21 & NR & NR & NR & NR & 29 & 10 & 19 & NR & NR & $N R$ & 23 \\
\hline & M: 84 & 48 & 36 & NR & $N R$ & NR & NR & 54 & 39 & 15 & NR & NR & $N R$ & 51 \\
\hline \multirow{2}{*}{$\begin{array}{l}\text { Hung et al. } \\
\text { [30] }\end{array}$} & C: 36 & 17 & 19 & 33 & $N R$ & NR & 24 & 25 & 10 & 15 & 8 & NR & $N R$ & 20 \\
\hline & M: 72 & 34 & 38 & 68 & NR & NR & 66 & 51 & 18 & 33 & 17 & NR & $N R$ & 52 \\
\hline \multirow{2}{*}{$\begin{array}{l}\text { Liu et al. } \\
\text { [36] }\end{array}$} & $C: 24$ & 14 & 7 & 16 & 10 & 6 & 12 & 9 & 3 & 6 & 7 & NR & NR & 9 \\
\hline & M: 30 & 17 & 13 & 25 & NR & NR & 23 & 18 & NR & $N R$ & 5 & NR & NR & 18 \\
\hline
\end{tabular}

C HBV and HCV coinfection, $M$ HCV mono-infection, NR not reported. 


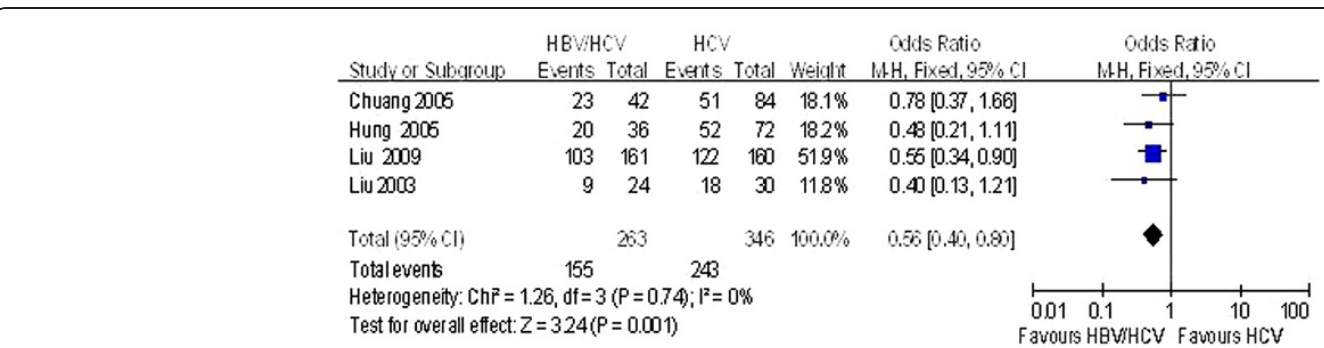

Figure 2 Comparison of the ALT normalization rates achieved at the end of follow up in HBV/HCV coinfection and HCV mono-infection patients.

RNA level varied from $2.16 \log _{10}$ [35] to $6.3 \log _{10}$ [35] copies/mL. Patients in three of the studies $[30,34,36]$ were treated with conventional interferon and ribavirin, patients in the other two studies [32,35] were treated with PEG-IFN (having a longer half-life) and ribavirin. Outcomes of the clinical trials included in the metaanalysis are presented in Table 2.

Comparison of serum ALT normalization rates achieved in $\mathrm{HBV} / \mathrm{HCV}$ coinfection patients and HCV mono-infection patients

Four of the studies [30,32,34,36] reported end of followup ALT normalization. Meta-analysis revealed that patients with $\mathrm{HBV} / \mathrm{HCV}$ coinfection have lower serum ALT normalization than those with HCV monoinfection at the end of follow-up $(P=0.001$; Figure 2). ALT normalization at the end of treatment in coinfection groups was also lower than in the HCV monoinfection groups $(P=0.04$; Figure 3$)$.

\section{Comparison of ETVR and SVR of HCV achieved in HBV/ HCV coinfection patients and HCV mono-infection patients}

The ETVR rate was similar between HBV/HCV coinfection groups and HCV mono-infection groups at the end of treatment $(85.98 \%$ vs. $86.36 \%, P=0.96)$. Morover, there was no significant difference in the SVR rate between the two groups at the end of follow-up (68.05\% vs. $70.41 \%, P=0.38)$. Detailed information can be found in Table 3.

\section{Comparison of the relapse of HCV between $\mathrm{HBV} / \mathrm{HCV}$ coinfection and HCV mono-infection}

The relapse of $\mathrm{HCV}$ rate was similar between $\mathrm{HBV} / \mathrm{HCV}$ coinfection groups and $\mathrm{HCV}$ mono-infection groups at the end of follow-up $(18.15 \%$ vs. $13.64 \%, P=0.06)$. The relapse of rate of $\mathrm{HCV}$ was also analyzed according to HCV genotype 1 and HCV non-genotype 1 (Table 3). The relapse of rates in both $\mathrm{HCV}$ genotype groups were similar between the $\mathrm{HBV} / \mathrm{HCV}$ coinfection groups and $\mathrm{HCV}$ mono-infection groups at the end of follow-up (HCV genotype 1: $21.26 \%$ vs. 9.62\%, $P=0.19$; HCV nongenotype 1: $8.33 \%$ vs. $9.86 \%, P=0.85$ ) (Table 3 ).

\section{Viral interaction of HBV and HCV in HCV/HBV coinfection patients}

All five [30,32,34-36] of the studies reported data for the HBV DNA level at baseline and at the end of follow-up in $\mathrm{HBV} / \mathrm{HCV}$ coinfection patients. In addition, data for the HBV DNA resurgence in patients with and without HCV SVR were reported (Table 4). The rate of HBV DNA resurgence in $\mathrm{HBV} / \mathrm{HCV}$ coinfection patients with HCV SVR was significantly higher than in those without HCV SVR $(\mathrm{OR}=3.36,95 \%$ CI: $1.35-8.38, P=0.009$, Figure 4).

\section{Discussion}

Several reports have revealed that $\mathrm{HBV}$ and $\mathrm{HCV}$ are capable of suppressing replication of each other in coinfection conditions. Dominant roles for both $\mathrm{HCV}$ and HBV have been suggested by some investigators

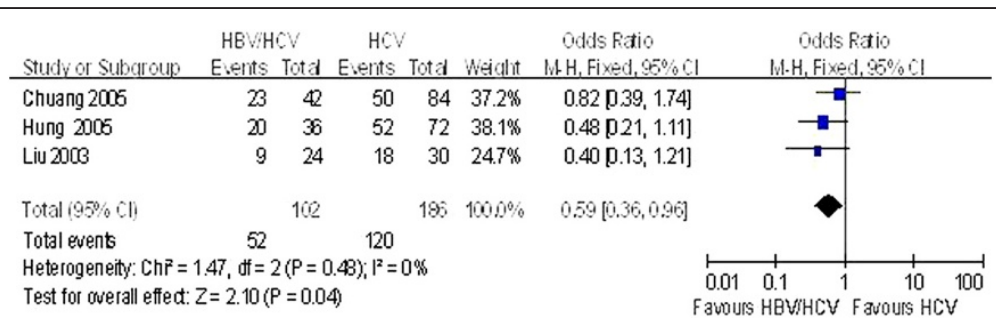

Figure 3 Comparison of the ALT normalization rates achieved at the end of treatment in HBV/HCV coinfection and HCV monoinfection patients. 
Table 3 Pooled effect of HBV/HCV coinfection studies with HCV mono-infection control studies

\begin{tabular}{|c|c|c|c|c|c|c|c|c|c|}
\hline \multirow[t]{2}{*}{ Effects } & \multicolumn{3}{|c|}{$\mathrm{HBV} / \mathrm{HCV}$} & \multicolumn{2}{|c|}{ HCV } & \multicolumn{2}{|c|}{ Effect size } & \multicolumn{2}{|c|}{ Heterogeneity } \\
\hline & Studies $(n)$ & Sample size & Events & Sample size & Events & OR(95\% Cl) & $P$ & $1^{2}$ & $P$ \\
\hline ETVR & 4 & 271 & 233 & 308 & 266 & $1.03(0.37-2.82)$ & 0.96 & $69 \%$ & 0.02 \\
\hline SVR & 5 & 313 & 213 & 392 & 276 & $0.87(0.62-1.21)$ & 0.38 & $0 \%$ & 0.61 \\
\hline HCV relapse & 4 & 270 & 49 & 308 & 42 & $1.55(0.98-2.47)$ & 0.06 & $47 \%$ & 0.13 \\
\hline HCV genotype 1 relapse & 2 & 127 & 27 & 135 & 13 & 2.4(1.17-4.91) & 0.19 & $74 \%$ & 0.05 \\
\hline HCV non-genotype 1 relapse & 2 & 84 & 7 & 71 & 7 & $0.9(0.3-2.71)$ & 0.85 & $0 \%$ & 0.40 \\
\hline
\end{tabular}

$O R$ odds ratio.

$[10,12,13]$. However, our meta-analysis indicates that HBV DNA was not always detectable in patients with $\mathrm{HBV} / \mathrm{HCV}$ coinfection, and that the rate of HBV DNA resurgence in $\mathrm{HBV} / \mathrm{HCV}$ coinfection patients with $\mathrm{HCV}$ SVR was significantly higher than in those without HCV SVR (31.11\% vs. 11.29\%, $P=0.009)$. These findings are consistent with the idea that patients with $\mathrm{HBV} /$ $\mathrm{HCV}$ coinfection show a large spectrum of virological profiles. It is possible that dominance of $\mathrm{HBV}$ or $\mathrm{HCV}$ may alternate at different periods during the infection. Thus, we speculate that one of the viruses in patients with $\mathrm{HBV} / \mathrm{HCV}$ coinfection is capable of exerting its particular pathogenic role and masking or silencing that of the other virus. Moreover, once the dominant virus becomes suppressed by treatment, the other may have a tendency towards reactivation. This type of robust activity elicited by one virus can explain the increased severity of disease observed in patients with $\mathrm{HBV} / \mathrm{HCV}$ coinfection, as opposed to that in patients with monoinfection of either of the two viruses.

The most commonly used clinical therapy to treat either HBV or HCV is interferon, usually administered as a subcutaneous injection. This drug was developed based upon the normal host antiviral and immunomodulatory actions that target invading viral pathogens for destruction and clearance. Previous studies have shown that patients with HCV mono-infection respond remarkably better to combination therapy (interferon supplemented with the nucleoside analogue ribavirin) than to interferon monotherapy (SVR of $43 \%$ vs. $10 \%$ ) [27,29,37,38]. Moreover, patients with CHB treated with conventional interferon achieved an SVR of $35 \%$ [28], and use of PEG-IFN achieves an even higher SVR in patients with $\mathrm{CHB}$ and $\mathrm{CHC}[39,40]$. To date, interferon has been the most studied pharmacologic agent for treatment of $\mathrm{HBV} / \mathrm{HCV}$ coinfected patients, because of its proven activity against both viruses. The efficacy of combination treatment with interferon plus ribavirin in $\mathrm{HBV} / \mathrm{HCV}$ coinfection patients has been assessed in various studies $[41,42]$, but very few studies to date have comparatively analyzed $\mathrm{HBV} / \mathrm{HCV}$ coinfection and HCV mono-infection, and the conclusions have been largely discordant [30-32]. Liu et al. [35] reported that the efficacy of combination therapy with PEG-IFN and ribavirin was similar between $\mathrm{HBV} / \mathrm{HCV}$ coinfected and HCV monoinfected patients. However, another study [34] showed that the HBV/HCV coinfected patients had higher ETVR and relapse rates than monoinfected patients.

Our meta-analysis confirmed that the combination treatment approach, with either conventional interferon or PEG-IFN plus ribavirin, achieved comparable ETVR and SVR in patients with $\mathrm{HBV} / \mathrm{HCV}$ coinfection and those with $\mathrm{HCV}$ mono-infection. Our analysis also showed that patients with $\mathrm{HBV} / \mathrm{HCV}$ coinfection were at similar risk of $\mathrm{HCV}$ relapse to those with $\mathrm{HCV}$

Table 4 Viral interaction of HBV and HCV in HCV/HBV-coinfected patients

\begin{tabular}{|c|c|c|c|c|c|c|c|c|c|c|}
\hline \multirow[t]{3}{*}{ Study } & \multirow{3}{*}{$\begin{array}{c}\text { Geographic } \\
\text { locale }\end{array}$} & \multirow{3}{*}{$\begin{array}{l}\text { Sample } \\
\text { size }(n)\end{array}$} & \multirow{2}{*}{\multicolumn{2}{|c|}{$\begin{array}{c}\text { Baseline HBV } \\
\text { DNA }(n)\end{array}$}} & \multicolumn{6}{|c|}{ End of follow-up ( $n$ ) } \\
\hline & & & & & \multirow{2}{*}{$\begin{array}{l}\text { HCV } \\
\text { SVR }\end{array}$} & \multirow{2}{*}{$\begin{array}{l}\text { Non- } \\
\text { HCV } \\
\text { SVR }\end{array}$} & \multirow{2}{*}{$\begin{array}{l}\text { Baseline HBV } \\
\text { DNA positive } \\
\text { HBV VR }\end{array}$} & \multicolumn{3}{|c|}{ HBV DNA resurgence } \\
\hline & & & Positive & Negative & & & & Overall & HCV SVR & $\begin{array}{c}\text { Non- HCV } \\
\text { SVR }\end{array}$ \\
\hline Yu et al. [35] & China & 50 & 4 & 46 & 27 & 23 & 4 & 11 & 9 & 2 \\
\hline Liu et al. [32] & Taiwan & 161 & 76 & 85 & 123 & 38 & 38 & 17 & NA & NA \\
\hline Chuang et al. [34] & Taiwan & 42 & 16 & 26 & 29 & 13 & 5 & 14 & 13 & 1 \\
\hline Hung et al. [30] & Taiwan & 36 & 18 & 18 & 25 & 11 & 3 & 6 & 4 & 2 \\
\hline Liu et al. [36] & Taiwan & 24 & 20 & 4 & 9 & 15 & 6 & 4 & 2 & 2 \\
\hline
\end{tabular}

$N A$ not available, $V R$ virological response (undetectable HBV DNA). 


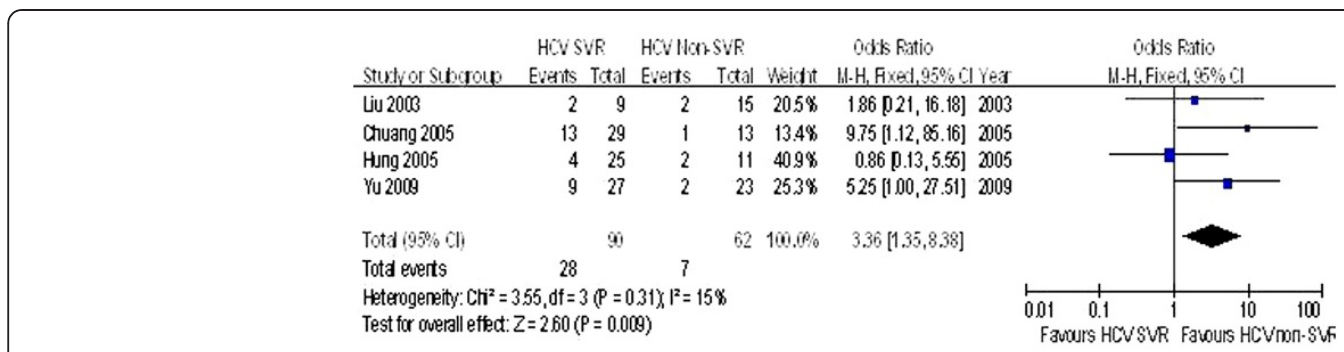

Figure 4 Comparison of the HBVDNA resurgence HCV SVR groups and HCV non-SVR groups in HBV/HCV coninfection patients.

mono-infection, regardless of the presence of $\mathrm{HCV}$ genotype 1 or HCV non-genotype 1 . However, combination treatment achieved higher ALT normalization in $\mathrm{HCV}$ mono-infection patients than in those with HBV/ $\mathrm{HCV}$ coinfection by the ends of both treatment and follow-up. According to the finding that eradication of one hepatitis virus in patients with $\mathrm{HBV} / \mathrm{HCV}$ coinfection may lead to increased titer of the other, we speculate that the resurgence of HBV might account for the persistent hepatitis activity after the clearance of $\mathrm{HCV}$. Therefore, examination of HBV antigens and HCV replication in the liver compartment is required to confirm this hypothesis.

These findings may provide insights into why the ALT normalization rate in patients with $\mathrm{HBV} / \mathrm{HCV}$ coinfection was lower than that in patients with HCV monoinfection. Yet undefined viral interactions and their impacts on treatment efficacy (for example, producing similar ETVR and SVR but lower ALT normalization) may explain the suppressive effect of HBV on $\mathrm{HCV}$ that has been observed in $\mathrm{HBV} / \mathrm{HCV}$ coinfected patients. Once the dominant HBV becomes suppressed by IFNbased therapy, coinfected patients may experience $\mathrm{HCV}$ reactivation and manifest $\mathrm{HCV}$-specific symptoms [21]. Therefore, clinicians should exercise caution when treating coinfected patients with combination therapy (the combination of PEG-IFN and ribavirin being the preferred strategy), and perform careful follow-up with systematic supervision. Larger scale studies should be carried out to determine whether prolonging the course of antiviral treatment in patients with $\mathrm{HBV} / \mathrm{HCV}$ coinfection will increase the risk of ALT normalization.

There are several limitations to our meta-analysis that should be considered prior to generalization of our findings. First, these five studies were composed exclusively of individuals of Asian descent. Second, conclusions were made based upon sub-analyses using calculated $p$-heterogeneity values. Third, the studies were not identical in the administered doses of interferon and ribavirin, types of interferon administered, or course of treatment; these differences in study design may explain the statistical heterogeneity. Fourth, the data of HCV relapse and ALT normalization in genotype 1 and non-genotype 1 infected patients were unavailable in some studies, which may have affected the accuracy of this meta-analysis.

In conclusion, the results of our meta-analysis demonstrate that combination treatment with interferon plus ribavirin achieves similar ETVR and SVR in HBV/HCV coinfection patients and $\mathrm{HCV}$ mono-infection patients. However, HBV/HCV coinfection patients achieve significantly lower ALT normalization and are at significantly higher risk of relapse. The combination of PEG-IFN and ribavirin is more effective than that of conventional interferon and ribavirin for both coinfection and monoinfection.

\section{Additional file}

Additional file 1: PRISMA 2009 Checklist.

\section{Abbreviations}

HBV: Hepatitis B Virus; HCC: Hepatocellular Carcinoma; CHB: Chronic Hepatitis B; CHC: Chronic Hepatitis C; HBsAg: Hepatitis B Surface Antigen; ALT: Alanine Aminotransferase; ETVR: End-of-Treatment Virological Response;

SVR: Sustained Virological Response; HIV: Human Immunodeficiency Virus; RR: Relative Risk; Cl: Confidence Interval; PEG-IFN: Pegylated-Interferon.

\section{Competing interests}

The funding source had no influence on study design, on the collection, analysis, and interpretation of the data, on the writing of the manuscript, or on the decision to submit this manuscript for publication. The contents are solely the responsibility of the authors and do not necessarily represent the views of the funding source.

\section{Authors' contributions}

$\mathrm{RH}$ and HP conceived the study, provided funding support, and revised the manuscript critically for intellectual content. LJY made substantial contributions to study design and data acquisition, analysis and interpretation. SYJ, TSW, HHD, ZQ, WJ, ZDZ and ZZ participated in the design of the study and data acquisition, analysis and interpretation. All authors read and approved the final manuscript.

\section{Acknowledgments}

This work was supported by grants from the National Natural Science Foundation of China (Nos. 30972584, 30930082 and 81171561), the National Science and Technology Major Project of China (Nos. 2008ZX10002-006 and 2012ZX10002-007), the Program for Changjiang Scholars and Innovative Research Team in University (No. IRT08720), Study Abroad for Chongqing Medical University Sponsored Staff.

Received: 10 December 2011 Accepted: 29 August 2012 Published: 6 September 2012 


\section{References}

1. Tong MJ, et al: Clinical outcomes after transfusion-associated hepatitis C. N Engl J Med 1995, 332(22):1463-1466.

2. Lauer GM, Walker BD: Hepatitis C virus infection. N Engl J Med 2001, 345(1):41-52.

3. Chisari FV: Hepatitis B virus transgenic mice: insights into the virus and the disease. Hepatology 1995, 22(4 Pt 1):1316-1325.

4. Tsai JF, et al: Hepatitis $C$ virus infection among patients with chronic liver disease in an area hyperendemic for hepatitis B. Scand J Gastroenterol 1994, 29(6):550-552.

5. Chen DS, et al: Hepatitis $C$ virus infection in an area hyperendemic for hepatitis B and chronic liver disease: the Taiwan experience. J Infect Dis 1990, 162(4):817-822.

6. Liu CJ, et al: Natural course and treatment of dual hepatitis B virus and hepatitis C virus infections. J Formos Med Assoc 2005, 104(11):783-791.

7. Liaw YF: Role of hepatitis $C$ virus in dual and triple hepatitis virus infection. Hepatology 1995, 22(4 Pt 1):1101-1108.

8. Sagnelli $\mathrm{E}$, et al: Multiple hepatitis virus infections in chronic $\mathrm{HBsAg}$ carriers in Naples. Arch Virol 1997, 142(3):445-451.

9. Cacciola I, et al: Occult hepatitis B virus infection in patients with chronic hepatitis C liver disease. N Engl J Med 1999, 341(1):22-26.

10. Squadrito $G$, et al: Virological profiles in patients with chronic hepatitis $C$ and overt or occult HBV infection. Am J Gastroenterol 2002, 97(6):1518-1523

11. Pontisso $P$, et al: Hepatitis $C$ genotypes in patients with dual hepatitis $B$ and C virus infection. J Med Virol 1996, 48(2):157-160.

12. Chu CM, Yeh CT, Liaw YF: Low-level viremia and intracellular expression of hepatitis B surface antigen ( $\mathrm{HBsAg}$ ) in $\mathrm{HBsAg}$ carriers with concurrent hepatitis C virus infection. J Clin Microbiol 1998, 36(7):2084-2086.

13. Jardi $R$, et al: Role of hepatitis $B, C$, and $D$ viruses in dual and triple infection: influence of viral genotypes and hepatitis $B$ precore and basal core promoter mutations on viral replicative interference. Hepatology 2001, 34(2):404-410

14. Fattovich $G$, et al: Hepatitis $C$ virus infection in chronic hepatitis $B$ virus carriers. J Infect Dis 1991, 163(2):400-402.

15. Donato F, Boffetta P, Puoti M: A meta-analysis of epidemiological studies on the combined effect of hepatitis $B$ and $C$ virus infections in causing hepatocellular carcinoma. Int J Cancer 1998, 75(3):347-354.

16. Mohamed Ael S, al Karawi MA, Mesa GA: Dual infection with hepatitis C and B viruses: clinical and histological study in Saudi patients. Hepatogastroenterology 1997, 44(17):1404-1406.

17. Lee LP, et al: Comparison of liver histopathology between chronic hepatitis C patients and chronic hepatitis B and C-coinfected patients. J Gastroenterol Hepatol 2007, 22(4):515-517.

18. Kaklamani $E$, et al: Hepatitis $B$ and $C$ viruses and their interaction in the origin of hepatocellular carcinoma. JAMA 1991, 265(15):1974-1976.

19. Kirk GD, et al: The Gambia Liver Cancer Study: infection with hepatitis B and $\mathrm{C}$ and the risk of hepatocellular carcinoma in West Africa. Hepatology 2004, 39(1):211-219.

20. Kanai K, Kako M, Okamoto H: HCV genotypes in chronic hepatitis C and response to interferon. Lancet 1992, 339(8808):1543.

21. Budillon $\mathrm{G}$, et al: Long-term follow-up evaluation in HCV chronic hepatitis treated with alpha-2b interferonA comparison of two protocols. Ital $J$ Gastroenterol 1994, 26(1):16-20

22. Alavian SM, Behnava B, Tabatabaei SV: Comparative efficacy and overall safety of different doses of consensus interferon for treatment of chronic HCV infection: a systematic review and meta-analysis. Eur J Clin Pharmacol 2010, 66(11):1071-1079.

23. Huang YW, et al: Differential effects of interferon and lamivudine on serum HBV RNA inhibition in patients with chronic hepatitis B. Antivir Ther 2010, 15(2):177-184.

24. Seo $Y$, et al: Early response to interferon alpha treatment and long-term clinical outcome in Japanese patients with chronic HBV genotype C infection. Int J Mol Med 2004, 13(1):75-79.

25. Liaw YF, et al: Response of patients with dual hepatitis B virus and C virus infection to interferon therapy. J Interferon Cytokine Res 1997 17(8):449-452

26. Zignego $\mathrm{AL}$, et al: Impaired response to alpha interferon in patients with an inapparent hepatitis B and hepatitis $C$ virus coinfection. Arch Virol 1997, 142(3):535-544.
27. Strader DB, et al: Diagnosis, management, and treatment of hepatitis C. Hepatology 2004, 39(4):1147-1171.

28. Wong DK, et al: Effect of alpha-interferon treatment in patients with hepatitis B e antigen-positive chronic hepatitis B. A metaanal Ann Intern Med 1993, 119(4):312-323.

29. Weltman MD, et al: Coinfection with hepatitis $B$ and $C$ or $B, C$ and delta viruses results in severe chronic liver disease and responds poorly to interferon-alpha treatment. J Viral Hepat 1995, 2(1):39-45.

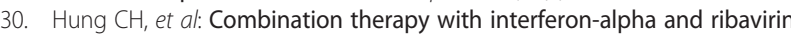
in patients with dual hepatitis B and hepatitis $C$ virus infection. J Gastroenterol Hepatol 2005, 20(5):727-732.

31. $\mathrm{Yu} \mathrm{ML}$, et al: $\mathrm{HBsAg}$ profiles in patients receiving peginterferon alfa- $2 \mathrm{a}$ plus ribavirin for the treatment of dual chronic infection with hepatitis $B$ and C viruses. J Infect Dis 2010, 202(1):86-92.

32. Liu CJ, et al: Peginterferon alfa-2a plus ribavirin for the treatment of dual chronic infection with hepatitis B and C viruses. Gastroenterology 2009 136(2):496-04e3.

33. Liberati $A$, et al: The PRISMA statement for reporting systematic reviews and meta-analyses of studies that evaluate health care interventions: explanation and elaboration. PLoS Med 2009, 6(7):p. e1000100.

34. Chuang $W L$, et al: Viral interaction and responses in chronic hepatitis $C$ and $\mathrm{B}$ coinfected patients with interferon-alpha plus ribavirin combination therapy. Antivir Ther 2005, 10(1):125-133.

35. Yu JW, et al: Analysis of the efficacy of treatment with peginterferon alpha-2a and ribavirin in patients coinfected with hepatitis $B$ virus and hepatitis C virus. Liver Int 2009, 29(10):1485-1493.

36. Liu CJ, et al: Ribavirin and interferon is effective for hepatitis $C$ virus clearance in hepatitis B and C dually infected patients. Hepatology 2003 , 37(3):568-576.

37. Burt MJ, et al: Concurrent hepatitis $B$ and $C$ infection treated successfully with alpha interferon. Aust N Z J Med 1993, 23(4):411-412.

38. Detry-Morel $M$, et al: Bilateral transient visual obscurations with headaches during alpha-II interferon therapy: a case report. Eur J Ophthalmol 1995, 5(4):271-274

39. Zeuzem S, et al: Peginterferon alfa-2a in patients with chronic hepatitis C. N Engl J Med 2000, 343(23):1666-1672.

40. Lee SD, et al: Comparison of a 6-month course peginterferon alpha- $2 b$ plus ribavirin and interferon alpha- $2 \mathrm{~b}$ plus ribavirin in treating Chinese patients with chronic hepatitis C in Taiwan. J Viral Hepat 2005, 12(3):283-291.

41. Marrone A, et al: Combined interferon plus lamivudine treatment in young patients with dual HBV (HBeAg positive) and HCV chronic infection. J Hepatol 2004, 41(6):1064-1065.

42. Urganci $\mathrm{N}$, et al: Interferon and ribavirin treatment results of patients with HBV-HCV co-infection cured of childhood malignancies. Int J Infect Dis 2006, 10(6):453-457.

doi:10.1186/1743-422X-9-186

Cite this article as: Liu et al:: The influence of hepatitis B virus on antiviral treatment with interferon and ribavirin in Asian patients with hepatitis $C$ virus/hepatitis B virus coinfection: a meta-analysis. Virology Journal 2012 9:186.

\section{Submit your next manuscript to BioMed Central and take full advantage of:}

- Convenient online submission

- Thorough peer review

- No space constraints or color figure charges

- Immediate publication on acceptance

- Inclusion in PubMed, CAS, Scopus and Google Scholar

- Research which is freely available for redistribution 